\title{
Insulin resistance in relatives of NIDDM patients: the role of physical fitness and muscle metabolism
}

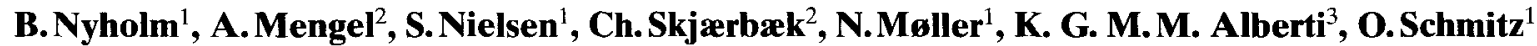 \\ ${ }^{1}$ Department of Medicine M (Endocrinology and Diabetes), Aarhus Kommunehospital, Aarhus, Denmark \\ ${ }^{2}$ Institute of Experimental and Clinical Research, University of Aarhus, Aarhus Kommunehospital, Aarhus, Denmark \\ ${ }^{3}$ Department of Medicine, The Medical School, Newcastle-upon-Tyne, UK
}

Summary First degree relatives of patients with noninsulin-dependent diabetes mellitus (NIDDM) are often reported to be insulin resistant. To examine the possible role of reduced physical fitness in this condition 21 first degree relatives of NIDDM patients and 22 control subjects without any history of diabetes were examined employing a 150-min hyperinsulinaemic $\left(0.6 \mathrm{mU}\right.$ insulin $\left.\cdot \mathrm{kg}^{-1} \cdot \mathrm{min}^{-1}\right)$ euglycaemic clamp combined with the isotope dilution technique $\left(3-{ }^{3} \mathrm{H}\right.$-glucose, Hot GINF), the forearm technique and indirect calorimetry. During hyperinsulinaemia glucose disposal (Rd) and forearm glucose extraction were significantly diminished in the relatives $(p<0.01$ and $p<0.05)$, but glucose oxidation and the suppressive effect on hepatic glucose production were normal. Arteriovenous differences across the forearm of the gluconeogenic precursors lactate, alanine and glycerol as well as the increments in forearm blood flow during hyperinsulinaemia were similar in the two groups. Maximal oxygen uptake $\left(\mathrm{VO}_{2} \max \right)$ was lower in the relatives than in the control subjects $\left(36.8 \pm 1.9\right.$ vs $\left.42.1 \pm 2.0 \mathrm{ml} \cdot \mathrm{kg}^{-1} \cdot \min ^{-1} ; p=0.03\right)$. There was a highly significant correlation between
$\mathrm{Rd}$ and $\mathrm{VO}_{2} \max$ in both relatives and control subjects $(r=0.68$ and 0.66 , respectively; both $p<0.001$ ). Comparison of the linear regression analyses of insulin-stimulated $\mathrm{Rd}$ on $\mathrm{VO}_{2}$ max in the two groups showed no significant differences between the slopes $(0.10 \pm 0.03$ vs $0.09 \pm 0.02)$ or the intercepts. In stepwise multiple linear regression analyses with insulinstimulated $\mathrm{Rd}$ as the dependent variable $\mathrm{VO}_{2} \max$ significantly determined the level of $\operatorname{Rd}(p<0.01)$, whereas forearm blood flow and anthropometric data did not. In conclusion, the insulin resistance in healthy first degree relatives of patients with NIDDM is associated with a diminished physical work capacity. Whether, this finding is ascribable to environmental or genetic factors (e.g. differences in muscle fibre types, capillary density etc) remains to be determined. [Diabetologia (1996) 39: 813-822]

Keywords Insulin resistance, relatives, non-insulindependent diabetes mellitus, oral glucose tolerance test, physical fitness, forearm blood flow, muscle metabolism.
Part of this work was presented at the 30th Annual Meeting of the European Association for the Study of Diabetes in Düsseldorf, Germany 1994.

Received: 8 September 1995 and in revised form: 13 December 1995

Corresponding author: Dr. O. Schmitz, Department of Medicine M (Endocrinology and Diabetes), Aarhus Kommunehospital, DK-8000 Aarhus C, Denmark
Abbreviations: BMI, Body mass index; W/H ratio, waist to hip ratio; FFM, fat free mass; NEFA, non-esterified fatty acids; $A-V$, arteriovenous; $\mathrm{VO}_{2}$ max, maximal oxygen uptake; GIR, glucose infusion rate; $\mathrm{Rd}$, isotopically determined glucose disposal; HGP, hepatic glucose production; $\operatorname{Rd}(\mathrm{ox})$, glucose oxidation rate; $\mathbf{R d}($ nonox), non-oxidative glucose disposal; lipid(ox), lipid oxidation rate; Protein(ox), protein oxidation rate; NIDDM, non-insulin-dependent diabetes mellitus; OGTT, oral glucose tolerance test. 
Insulin resistance is considered to be one cardinal feature in the pathogenesis of non-insulin-dependent diabetes mellitus (NIDDM) [1-3]. Employing various techniques for assessment of insulin sensitivity both cross-sectional [4-13] and prospective studies [14-16] in subjects with an increased risk for developing NIDDM such as offspring of patients with NIDDM and Pima Indians, support this hypothesis. Normal glucose tolerant healthy first degree relatives of patients with NIDDM are characterized by an impaired insulin-stimulated glucose uptake [non-oxidative) compared to subjects without any family history of diabetes $[5,6,11,12]$.

Physical work capacity is a major determinant of insulin sensitivity. Using the hyperinsulinaemic euglycaemic clamp technique many investigators have demonstrated a strong correlation between wholebody insulin-stimulated glucose uptake and maximal oxygen uptake in healthy humans [e.g. 17, 18]. Furthermore, a single bout of exercise improves insulin action on glucose metabolism for several hours to days $[19,20]$, whereas detraining conversely causes a deterioration in insulin action [18]. An association between a low level of physical activity and an increased occurrence of NIDDM has recently been demonstrated in two large prospective studies [21, 22]. Nevertheless, a possible direct relationship between the magnitude of insulin resistance in relatives of NIDDM patients and their physical fitness has not been tested.

In addition, an impaired ability of insulin to stimulate skeletal muscle blood flow has been suggested to be an important mechanism contributing to the impaired insulin-stimulated glucose uptake in fullblown insulin resistance conditions, such as NIDDM and obesity [23-26]. The abnormality could provide an important link between hypertension and insulin resistance [27]. Whether the impact of hyperinsulinaemia on muscle blood flow is normal in subjects with an enhanced risk of developing NIDDM has so far not been examined.

Thus, the present investigation was undertaken to gain further insight into the possible roles of: (i) a diminished physical capacity; and (ii) abnormalities in insulin-stimulated skeletal muscle blood flow as pathogenic factors behind the insulin resistance of first degree relatives of NIDDM patients.

\section{Subjects and methods}

Subjects. Twenty-one healthy offspring of NIDDM patients and 22 healthy control subjects without any family history of diabetes participated in the study. The relatives were recruited via their NIDDM parents attending the outpatient clinic, Medical Department M, Aarhus Kommunehospital. Ten of the relatives had one known family member (first degree) with NIDDM (one parent), ten had two or more (one first degree and one or more second degree relatives) and one had two first
Table 1. Clinical data of the two groups

\begin{tabular}{|c|c|c|}
\hline & $\begin{array}{l}\text { Relatives } \\
(n=21)\end{array}$ & $\begin{array}{l}\text { Control subjects } \\
(n=22)\end{array}$ \\
\hline Gender (male/female) & $11 / 10$ & $13 / 9$ \\
\hline Age (years) & $37.6(27-53)$ & $35.4(21-50)$ \\
\hline BMI $\left(\mathrm{kg} / \mathrm{m}^{2}\right)$ & $24.8(16.8-30.0)$ & $24.0(18.8-29.2)$ \\
\hline Waist/hip ratio & $0.90(0.77-1.03)$ & $0.89(0.73-1.06)$ \\
\hline Fat free mass $(\mathrm{kg})$ & $56.9(39.3-75.7)$ & $56.9(40.9-73.1)$ \\
\hline $\mathrm{VO}_{2} \max \left(\mathrm{ml} \cdot \mathrm{kg}^{-1} \cdot \mathrm{min}^{-1}\right)$ & $36.8(19.5-55.5)$ & $42.1(24.0-65.6)^{\mathrm{a}}$ \\
\hline Number of smokers & 9 & 8 \\
\hline \multicolumn{3}{|l|}{$\begin{array}{l}\text { Systolic blood pressure } \\
(\mathrm{mm} \mathrm{Hg})\end{array}$} \\
\hline Day-time & $127(110-135)$ & $128(96-134)$ \\
\hline Night-time & $110(95-120)$ & $112(90-130)$ \\
\hline $24-\mathrm{h}$ & $122(106-132)$ & $123(94-135)$ \\
\hline \multicolumn{3}{|l|}{$\begin{array}{l}\text { Diastolic blood pressure } \\
(\mathrm{mm} \mathrm{Hg})\end{array}$} \\
\hline Day-time & $79(61-85)$ & $79(63-84)$ \\
\hline Night-time & $63(51-75)$ & $63(50-80)$ \\
\hline $24-\mathrm{h}$ & $74(59-84)$ & $74(60-84)$ \\
\hline $\begin{array}{l}\text { Urinary albumin/creatinine } \\
\text { ratio }(\mathrm{mg} / \mathrm{mmol})\end{array}$ & $0.51(0.10-1.33)$ & $0.46(0.07-0.87)$ \\
\hline Serum lipids ( $\mathrm{mmol} / \mathrm{l}$ ) & & \\
\hline $\begin{array}{l}\text { Total cholesterol } \\
\text { HDL-cholesterol }\end{array}$ & $5.23(3.3-6.5)$ & $4.94(3.2-6.4)$ \\
\hline $\begin{array}{l}\text { HDL-cholesterol } \\
\text { Triglycerides }\end{array}$ & $1.41(0.80-2.52)$ & $1.27(0.57-1.83)$ \\
\hline Triglycerides & $1.04(0.41-2.28)$ & $1.07(0.53-2.09)$ \\
\hline
\end{tabular}

Data are mean (range)

${ }^{\mathrm{a}} p=0.03$. All other comparisons $p>0.25$

degree relatives with NIDDM. Ten had a maternal and 11 had a paternal history. All were healthy and were taking no medication. No family history of any other endocrine disorder was present. Additional exclusion criteria were age over 54 years, BMI over $30 \mathrm{~kg} / \mathrm{m}^{2}$ and non-Caucasian origin. If two or more offspring were available in a family, only one was randomly (by chance) selected to participate. The control group was recruited from volunteer blood donors, medical students, physicians and nurses. The pertinent clinical data of the two groups are depicted in Table 1.

All were instructed to consume a weight-maintaining diet containing at least $300 \mathrm{~g}$ of carbohydrate for 3 days prior to both examinations (see below) and none was engaged in heavy physical exercise in the same periods. None had a history of infectious disease within the 4 weeks prior to the study. All females were examined in the follicular phase of the menstrual cycle, one in each group was postmenopausal.

The protocol was approved by the ethical committee of the County of Aarhus.

Design. All subjects were tested twice on two separate occasions (Test I and II) with an interval of 2 to 4 weeks.

\section{Test I}

After an overnight fast the subjects underwent a physical examination including determination of waist to hip $(\mathrm{W} / \mathrm{H})$ ratio and fat free mass (FFM) employing bioelectric impedance (Animeter; HTS-Engineering APS, Odense, Denmark) [28]. At 08.00 hours an oral glucose tolerance test (OGTT) (75 g glucose) was performed. Blood for determination of plasma glucose, serum insulin, C-peptide, and non-esterified fatty 
acids (NEFA) was taken at time $0,30,60,90$ and $120 \mathrm{~min}$. Blood for determination of serum triglycerides, total cholesterol, and HDL-cholesterol was collected at time 0 .

After termination of the OGTT a 6-min submaximal exercise test with continuous monitoring of the heart rate, was performed on a bicycle ergometer (Monark Ergometric 829 E; Monark Exercise AB, Varberg, Sweden) using a workload of $300-1500 \mathrm{kpm} / \mathrm{min}$, depending on age, gender and reported physical activity by the subject. The mean heart rate during the last $2 \mathrm{~min}$ of work ( $>120-130 \mathrm{beats} / \mathrm{min}$ ) was used for calculation of the maximal aerobic capacity $\left(\mathrm{VO}_{2} \max \right)$ as described by Astrand [29]. This indirect measure of $\mathrm{VO}_{2}$ max has been shown to correlate well to $\mathrm{VO}_{2}$ max as determined by direct measurements with a coefficient of variance of less than $10 \%[30,31]$. The level of habitual physical activity, both during work and leisure, was quantified using a questionnaire according to Saltin and Grimby [32].

Finally, after a light meal measurement of 24-h ambulatory blood pressure was started by a portable lightweight monitor (Spacelabs 90202, Redmond, Wash., USA). The monitor was programmed to measure blood pressure every $20 \mathrm{~min}$ during daytime (06.00 to 24.00 hours) and every $60 \mathrm{~min}$ during the night. The procedure has been described elsewhere [33]. On the following morning subjects were instructed to collect their first morning urine sample for assessment of the albumin/creatinine ratio.

\section{Test II}

All studies started at 08.00 hours in the clinical research unit after a 10-h overnight fast. One catheter was inserted retrogradely into a deep antecubital vein of one arm for sampling of blood derived from the forearm muscles. The criteria for satisfactory positioning was that the oxygen saturation in blood drawn from the catheter was under $70 \%$. In the contralateral arm, one catheter was placed in a heated dorsal hand vein for sampling of arterialized blood (oxygen saturation $>90 \%$ ), and another was positioned in the antecubital vein for all infusions.

At 08.30 hours (time $0 \mathrm{~min}$ ) a $20 \mu \mathrm{Ci}$ bolus dose of $3-{ }^{3} \mathrm{H}$ glucose (DuPont-New England Nuclear, Boston, Mass., USA) was given followed by infusion at a constant rate of $0.20 \mu \mathrm{Ci}$ / min throughout the study. As assessed by HPLC the tracer contained no significant contamination [34]. After $150 \mathrm{~min}$, insulin (Actrapid; Novo-Nordisk, Copenhagen, Denmark) was infused intravenously at a constant rate of $0.6 \mathrm{mU} \cdot \mathrm{kg}^{-1} \cdot \mathrm{min}^{-1}$ for $150 \mathrm{~min}$ (time, $150-300 \mathrm{~min}$ ). Plasma glucose was clamped at $5 \mathrm{mmol} / \mathrm{l}$ as described by DeFronzo et al. [35]. To minimize rapid dilution of the labelled glucose pool with unlabelled glucose, $3-{ }^{3} \mathrm{H}$ glucose was added to the glucose infused during the clamp $(100 \mu \mathrm{Ci} / 500 \mathrm{ml} 20 \%$ glucose $)$ [36]. Blood for determination of glucose specific activity and serum insulin were drawn at times $0,90,120,135,150,180,210,240,270,285$ and $300 \mathrm{~min}$. The intervals between 120 and $150 \mathrm{~min}$ and 270 and $300 \mathrm{~min}$ were defined as the basal state and the hyperinsulinaemic 'steady-state' period, respectively. Indirect calorimetry [37] (Deltatrac Metabolic Monitor; Datex, Helsinki, Finland), measurements of forearm blood flow [38] (Venous occlusion plethysmography; Digimatic 2000; Medimatic A/S, Copenhagen, Denmark) and examination of arteriovenous (A-V) substrate balances [39] were performed in these two periods.

Plasma glucose was determined every 5-10 min during the clamp. Serum NEFA and blood alanine, lactate, glycerol and 3-hydroxy-butyrate were measured every $15 \mathrm{~min}$ in the basal state and the steady-state period.
Analytical methods. Plasma glucose was measured in duplicate immediately after sampling (Beckman Instruments, Palo Alto, Calif., USA). Serum insulin was determined by RIA as described by $\varnothing$ rskov et al. [40] with modifications. Circulating insulin during the OGTT was also assayed by ELISA employing a two-site immunoassay [41], which does not detect proinsulin, split(32-33)-, and des(31,32)-proinsulin, whereas split(65-66)and des(64-65)-proinsulin crossreact $30 \%$ and $63 \%$, respectively. The intraassay coefficient of variation (C. V.) was $2.0 \%$ $(n=75)$ at a serum level of $200 \mathrm{pmol} / \mathrm{l}$. Serum C-peptide was determined according to Heding [42]. Serum NEFA was determined by a colorimetric method employing a commercial kit (Wako Chemicals, Neuss, Germany). Blood lactate, glycerol, 3-hydroxy-butyrate and alanine were assayed using a Cobas Bio centrifugal analyzer with a fluorometric attachment [43].

Calculations. After counting plasma glucose specific activity the non-steady-state equation as described by Finegood et al. [36] was used for calculation of glucose appearance/disposal rates. A pool fraction of 0.65 and a distribution volume of $220 \mathrm{ml} / \mathrm{kg}$ were employed. Respiratory exchange ratios were assessed employing indirect calorimetry. Protein oxidation rates were estimated from urinary excretion of urea. Net lipid oxidation and glucose oxidation rates were computed from the above measurements, and non-oxidative glucose disposal was calculated by subtracting the glucose oxidation rate from total isotopically determined glucose disposal.

Calculation of forearm blood flow was performed blind and was based upon the average of measurements made in triplicate in each of the two periods.

\section{Statistical analyses}

Data in the text and figures are given as means \pm SEM. Student's two-tailed $t$-tests for unpaired and paired data were used for comparison of data between and within groups, respectively. Student's one-tailed $t$-test for unpaired data was used to test the hypothesis that $\mathrm{VO}_{2} \max$ was decreased in relatives of NIDDM patients. When data were not parametrically distributed (urinary albumin/creatine ratio) Mann-Whitney's Rank sum test for unpaired data was used. In addition twoway analysis of variance (ANOVA) for repeated measures, Pearson Product moment correlation test, linear- and stepwise multiple linear regression analyses were used. Finally, chi square analysis was employed to test the results of the questionnaire.

\section{Results}

Oral glucose tolerance test. Neither fasting plasma glucose nor serum insulin and C-peptide were different $(p>0.10)$ in the basal state prior to the OGTT between the two groups (Table 2). $\mathrm{HbA}_{1 \mathrm{c}}$ tended, however, to be higher in the relatives $(5.15 \pm 0.11 \%)$ than in the control subjects $(4.85 \pm 0.13 \%, p=0.09)$. During the OGTT plasma glucose was more elevated in the relatives after 60,90 and $120 \mathrm{~min}$ compared to the control subjects $(p=0.05, p<0.05$ and $p=0.08$, respectively) (Fig. 1). However, all subjects exhibited a normal OGTTaccording to the criteria of the National Diabetes Data Group [44]. Following the glucose challenge average serum insulin values as determined by a 
Table 2. Basal plasma glucose, serum NEFA and circulating insulin and C-peptide prior to OGTT

\begin{tabular}{lcc}
\hline & Relatives & Control subjects \\
\hline Plasma glucose (mmol/l) & $5.3 \pm 0.1$ & $5.1 \pm 0.1$ \\
Serum NEFA (mmol/l) & $0.62 \pm 0.06$ & $0.57 \pm 0.07$ \\
Serum insulin (RIA) (pmol/l) & $38 \pm 8$ & $43 \pm 5$ \\
Serum insulin (ELISA) (pmol/l) & $44 \pm 8$ & $39 \pm 3$ \\
Serum C-peptide (nmol/l) & $0.47 \pm 0.04$ & $0.41 \pm 0.04$ \\
\hline
\end{tabular}

Data are mean \pm SEM

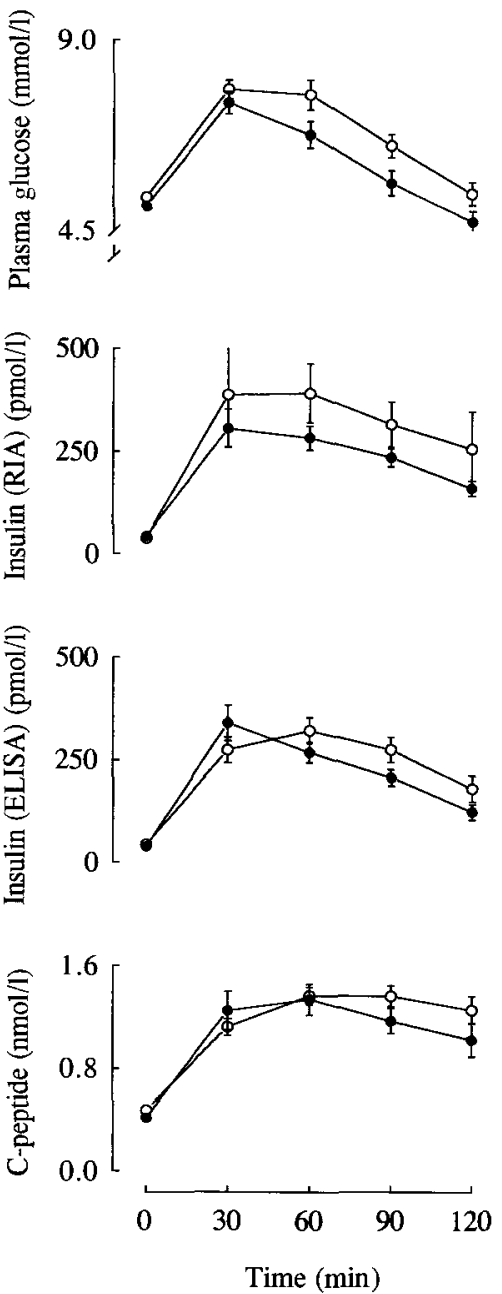

Fig. 1. Plasma glucose (mean $\pm S E M$ ), serum insulin (measured by RIA and by ELISA using a two-site immunoassay) and C-peptide during a 75-g OGTT in 21 first degree relatives of patients with NIDDM $(\bigcirc)$ and 22 control subjects with no family history of diabetes mellitus (O)

traditional RIA tended to be higher in the relatives although these differences were not statistically significant owing to large variations in the group. By contrast, the profiles of circulating insulin as measured by ELISA using a highly specific two-site immunoassay and circulating C-peptide following OGTT were different in the relatives and the control subjects (ANOVA; $p<0.01$ and $p=0.05$ ). Both curves showed a sluggish initial response in the relatives, but the areas under the curves using the trapezoidal rule were comparable in the two groups $(p>0.10)$. Basal NEFA was comparable in the two groups.

Physical capacity/activity. There was a large overlap in maximal oxygen consumption as assessed by bicycle ergometer in the two groups. However, on average $\mathrm{VO}_{2} \max$ was approximately $15 \%$ higher in the control subjects than in the relatives $(p=0.03$, Table 1). Assessment of habitual physical activity by questionnaire [32] did not disclose any differences in the level of activity between the relatives and the control subjects, during work or during leisure.

Glucose metabolism. There was no difference in basal metabolism between the two groups (Table 3). During hyperinsulinaemia (steady-state serum insulin: $379 \pm 20$ vs $371 \pm 13 \mathrm{pmol} / \mathrm{l}$; steady-state plasma glucose: $5.1 \pm 0.1$ vs $5.1 \pm 0.0 \mathrm{mmol} / \mathrm{l}$; relatives vs control subjects) rates of glucose infusion (GIR), isotopically determined total glucose disposal (Rd) and non-oxidative glucose disposal (Rd(nonox)) were all decreased in the relatives as compared to the control subjects ( $p=0.05$ or less, Table 3 ). Similar discrepancies were found when expressing the data as $\mathrm{mg}$. $\mathrm{kg} \cdot \mathrm{FFM}^{-1} \cdot \mathrm{min}^{-1}$ (data not shown). By contrast, oxidative glucose disposal ( $\operatorname{Rd}(\mathrm{ox}))$, lipid oxidation (lipid(ox)) and hepatic glucose production (HGP) were all similar during hyperinsulinaemia in the two groups (Table 3). As indicated in Figure 2, GIR and Rd were diminished in the relatives after $60 \mathrm{~min}$ of hyperinsulinaemia, while HGP was uniformly suppressed during the period of hyperinsulinaemia. Insulin-stimulated $\mathrm{Rd}$ was similar in the subjects with a paternal $\left(4.59 \pm 0.35 \mathrm{mg} \cdot \mathrm{kg}^{-1} \cdot \mathrm{min}^{-1}\right)$ and a maternal history of NIDDM $\left(4.81 \pm 0.49 \mathrm{mg} \cdot \mathrm{kg}^{-1} \cdot \mathrm{min}^{-1}\right)$. Likewise, $\mathrm{Rd}$ was comparable in the relatives with only one known and two or more known relatives with NIDDM $\left(4.52 \pm 0.38\right.$ vs $4.85 \pm 0.45 \mathrm{mg} \cdot \mathrm{kg}^{-1}$. $\left.\min ^{-1}\right)$.

Relationship between glucose metabolism and physical capacity. There was a highly significant correlation between $\mathrm{Rd}$ and $\mathrm{VO}_{2}$ max in both relatives and control subjects ( $r=0.68$ and 0.66 , respectively; $p$ (both) $<0.001)$. A linear model was found to give the best description of this relationship in the two groups separately and together (Fig. 3). When comparing the linear regression analyses of insulin-stimulated $\mathrm{Rd}$ on $\mathrm{VO}_{2}$ max in the two groups no significant differences between the slopes $(0.10 \pm 0.03$ vs $0.09 \pm 0.02)$ or the intercepts $(0.92 \pm 0.95$ vs $1.71 \pm 1.05 \mathrm{mg} \cdot \mathrm{kg}^{-1} \cdot \mathrm{min}^{-1}$ ) were found. A linear relationship was also found between GIR and $\mathrm{Rd}$ (nonox) and $\mathrm{VO}_{2} \max (p<0.01)$.

In stepwise multiple linear regression analyses with insulin-stimulated $\mathrm{Rd}$ as the dependent variable 
Table 3. Basal and insulin-stimulated glucose and lipid metabolism $\left(\mathrm{mg} \cdot \mathrm{kg}^{-1} \cdot \mathrm{min}^{-1}\right)$

\begin{tabular}{lrcl}
\hline & Relatives & Control subjects & $p$ value \\
\hline Basal & & & \\
Rd & $1.75 \pm 0.08$ & $1.75 \pm 0.06$ & NS \\
Rd (ox) & $0.99 \pm 0.11$ & $1.03 \pm 0.07$ & NS \\
Rd (nonox) & $0.76 \pm 0.10$ & $0.72 \pm 0.08$ & NS \\
Lipid (ox) & $1.04 \pm 0.04$ & $1.07 \pm 0.05$ & NS \\
HGP & $1.79 \pm 0.09$ & $1.78 \pm 0.07$ & NS \\
Protein (ox) & $0.58 \pm 0.03$ & $0.57 \pm 0.04$ & NS \\
Hyperinsulinaemia & & & \\
GIR & $4.82 \pm 0.32$ & $6.03 \pm 0.33$ & $p=0.01$ \\
Rd & $4.69 \pm 0.29$ & $5.67 \pm 0.29$ & $p<0.05$ \\
Rd (ox) & $2.26 \pm 0.15$ & $2.41 \pm 0.11$ & NS \\
Rd (nonox) & $2.56 \pm 0.22$ & $3.73 \pm 0.25$ & $p<0.01$ \\
Lipid (ox) & $0.48 \pm 0.06$ & $0.47 \pm 0.04$ & NS \\
HGP & $-0.24 \pm 0.13$ & $-0.36 \pm 0.12$ & NS
\end{tabular}

Data are mean \pm SEM

$\mathrm{Rd}$, Rd (ox) and Rd (nonox): Isotopically determined total glucose disposal, glucose oxidation and nonoxidative glucose disposal, respectively. Lipid (ox): Lipid oxidation. Protein (ox): Protein oxidation

$\mathrm{VO}_{2}$ max statistically significantly determined the level of $\mathrm{Rd}$ in both relatives and control subjects $(p<0.01)$, whereas basal and insulin-stimulated blood flow, anthropometric data, age, gender, basal insulin and NEFA levels, 24-h ambulatory blood pressure, lipid profile and urinary albumin/creatinine ratio (entered separately and together with $\mathrm{VO}_{2} \max$ as independent variables) did not further significantly contribute to the level of $\mathrm{Rd}$.

Forearm blood flow. Forearm blood flow did not differ significantly in the basal state between the relatives $\left(1.62 \pm 0.15 \mathrm{ml} \cdot 100 \mathrm{ml}\right.$ tissue $\left.\mathrm{e}^{-1} \cdot \mathrm{min}^{-1}\right)$ and the control subjects $\left(2.06 \pm 0.22 \mathrm{ml} \cdot 100 \mathrm{ml}\right.$ tissue $^{-1}$. $\min ^{-1} ; p=0.12$ ). During the clamp (and hyperinsulinaemia) forearm blood flow rose in both groups (relatives and control subjects: $p<0.05$ and $p<0.01$; respectively) (Fig. 4). Forearm blood flow was higher in the control subjects $(2.53 \pm 0.27 \mathrm{ml} \cdot 100 \mathrm{ml}$ tis$\left.\mathrm{sue}^{-1} \cdot \mathrm{min}^{-1}\right)$ than in the relatives $(1.86 \pm 0.12 \mathrm{ml}$. $100 \mathrm{ml}$ tissue $\left.{ }^{-1} \cdot \mathrm{min}^{-1} ; p<0.05\right)$. The increments in blood flow did not, however, differ between the two groups (relatives vs control subjects: $0.24 \pm 0.10 \mathrm{vs}$ $0.47 \pm 0.14 \mathrm{ml} \cdot 100 \mathrm{ml}$ tissue ${ }^{-1} \cdot \mathrm{min}^{-1} ; \quad p=0.18$ ). There was no correlation between increments in blood flow and Rd in the two groups $(r=0.16$ and $r=0.07 ; p($ both $)>0.50)$.

NEFA, metabolites and A-V balances. Basal arterialized levels of NEFA, glycerol, 3-hydroxy-butyrate, lactate and alanine were similar in the relatives and the control subjects (Table 4). Following hyperinsulinaemia, the variables were affected equally in the two groups. Serum NEFA, blood 3-hydroxy-butyrate and blood glycerol were greatly reduced $(p<0.001)$, while blood lactate increased significantly $(p<0.001)$.
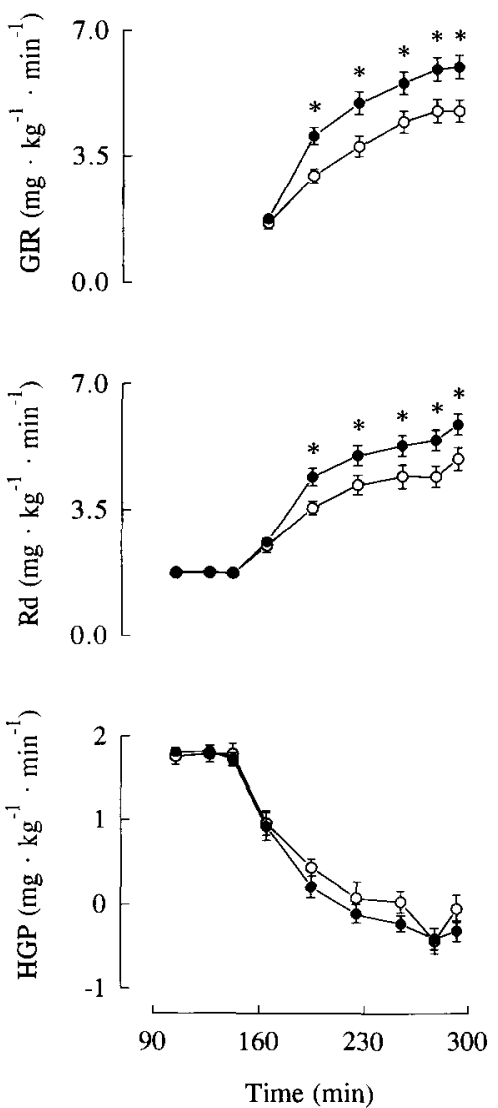

Fig. 2. Rates of glucose infusion (GIR) (mean \pm SEM), isotopically determined glucose disposal (Rd) and hepatic glucose production (HGP) in the basal state and during the hyperinsulinaemic clamp (time, $150-300 \mathrm{~min}$ ) in relatives $(\bigcirc)$ and control subjects $(\bigcirc) .{ }^{*} p<0.05$

Blood alanine was not influenced by the insulin infusion (Table 4). A-V differences of the metabolites during insulin exposure did not differ between the two groups. A-V differences of the gluconeogenic precursors, lactate and alanine were $-0.040 \pm 0.015$ and $-0.01 \pm 0.003 \mathrm{mmol} / 1$, respectively in the relatives and $-0.036 \pm 0.013$ and $-0.028 \pm 0.003 \mathrm{mmol} / \mathrm{l}$ in the control subjects. A-V differences in blood glycerol and 3-hydroxy-butyrate were close to zero in both groups during hyperinsulinaemia.

A-V differences of plasma glucose across the forearm during insulin stimulation were comparable in the relatives $(0.91 \pm 0.11 \mathrm{mmol} / \mathrm{l})$ and the control subjects $(1.05 \pm 0.15 \mathrm{mmol} / \mathrm{l}, \quad p=0.39)$. However, there was a significant correlation between A-V differences in plasma glucose and isotopically determined $\mathrm{Rd}$ among all subjects $(r=0.76, p<0.001)$. In contrast insulin-stimulated forearm glucose disposal, determined by multiplying the forearm blood flow and $\mathrm{A}-\mathrm{V}$ differences in plasma glucose $[39,45]$, was significantly reduced in the relatives $(1.37 \pm 0.20$ $\mu \mathrm{mol} \cdot 100 \mathrm{ml}$ tissue ${ }^{-1} \cdot \mathrm{min}^{-1}$ ) as compared to the control subjects $\left(1.94 \pm 0.26 \mu \mathrm{mol} \cdot 100 \mathrm{ml}\right.$ tissue $^{-1}$. $\mathrm{min}^{-1} ; p($ ANOVA $)<0.05$; Fig. 5$)$. As expected, there 


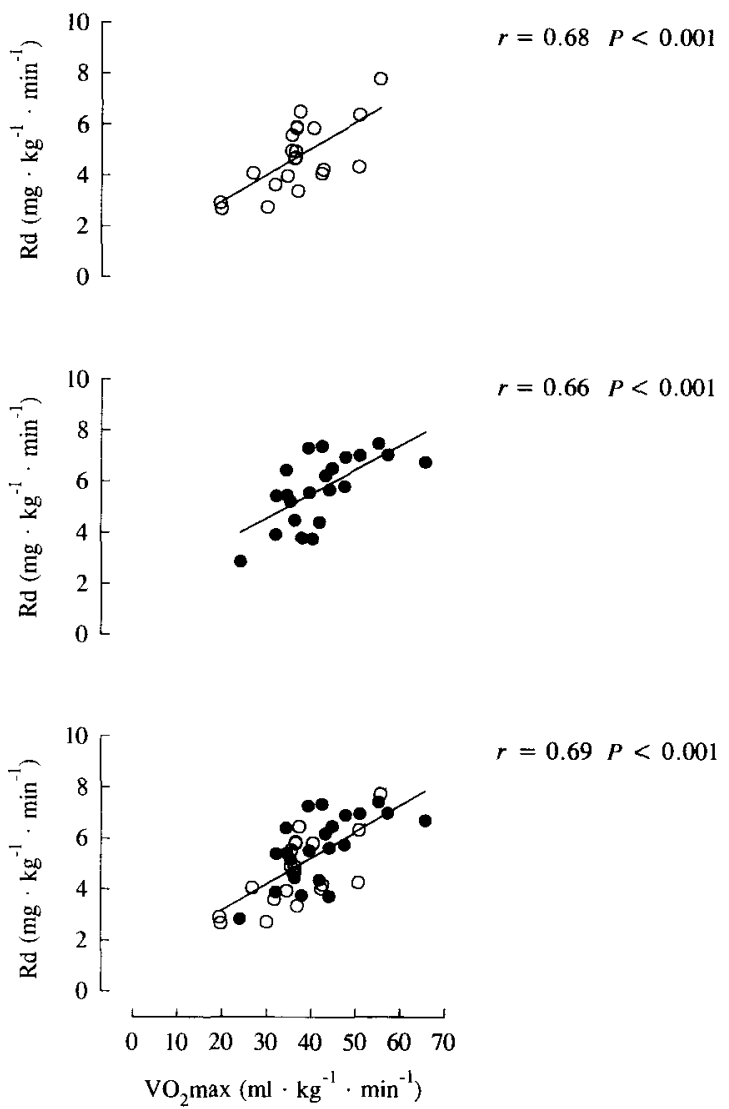

Fig. 3. Linear regression line between insulin-stimulated $\mathrm{Rd}$ and $\mathrm{VO}_{2}$ max in relatives of patients with NIDDM (O) and control subjects $(\bigcirc)$, and in the two groups together

Table 4. Arterialized serum NEFA, blood glycerol, 3-hydroxybutyrate, lactate and alanine in the basal state and during hyperinsulinaemic clamp ( $\mathrm{mmol} / \mathrm{l})$

\begin{tabular}{lll}
\hline & Relatives & Control subjects \\
\hline Basal & & \\
NEFA & $0.655 \pm 0.033$ & $0.604 \pm 0.032$ \\
Glycerol & $0.056 \pm 0.002$ & $0.051 \pm 0.003$ \\
3-hydroxy-butyrate & $0.130 \pm 0.029$ & $0.090 \pm 0.018$ \\
Lactate & $0.521 \pm 0.015$ & $0.509 \pm 0.025$ \\
Alanine & $0.207 \pm 0.027$ & $0.205 \pm 0.019$ \\
Hyperinsulinaemia & & \\
NEFA & $0.036 \pm 0.005$ & $0.036 \pm 0.004$ \\
Glycerol & $0.021 \pm 0.001$ & $0.021 \pm 0.001$ \\
3-hydroxy-butyrate & $0.003 \pm 0.001$ & $0.005 \pm 0.001$ \\
Lactate & $0.641 \pm 0.020$ & $0.644 \pm 0.012$ \\
Alanine & $0.195 \pm 0.007$ & $0.191 \pm 0.006$ \\
\hline
\end{tabular}

Data are mean \pm SEM

was a highly significant relationship between forearm glucose disposal and whole-body $\mathrm{Rd}(r=0.75, p<$ 0.001 ).

Blood pressure, lipid parameters and urinary albumin /creatinine ratio. 24-h ambulatory blood pressure, daytime and night-time blood pressure were almost identical in the two groups. There was no correlation

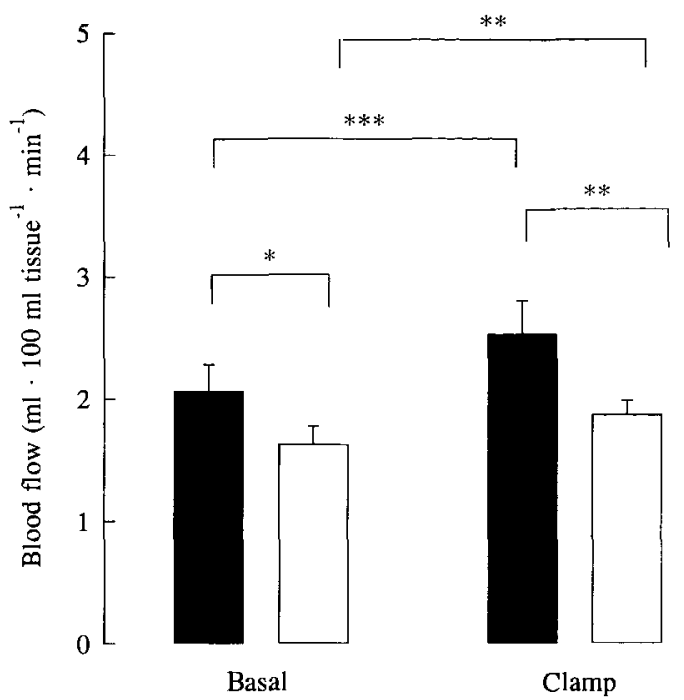

Fig. 4. Forearm blood flow (mean \pm SEM) in the basal state and during the hyperinsulinaemic clamp in relatives ( $\square$ ) and control subjects (ロ). ${ }^{*} p=\mathrm{NS} ;{ }^{* *} p<0.05 ;{ }^{* * *} p<0.01$

between either systolic blood pressure or diastolic blood pressure and GIR or $\mathrm{Rd}(p($ all $)>0.5)$. Similarly, serum levels of total cholesterol, HDL-cholesterol and triglycerides were also comparable, and no difference in urinary albumin/creatinine ratio was observed (Table 1).

\section{Discussion}

One of the novel observations in the present study was that the insulin resistance of the relatives of patients with NIDDM was related to their maximal aerobic oxygen uptake. The relationship between $\mathrm{VO}_{2}$ max and insulin-stimulated glucose disposal was close and almost identical in the relatives and control subjects, but $\mathrm{VO}_{2} \max$ was on average $15 \%$ lower in the relatives. The data does not allow conclusions about causality, but it is tempting to hypothesyse the decreased physical work capacity as being one cardinal determinant behind the insulin resistance of the relatives of NIDDM patients.

In some of the previous studies evaluating insulin sensitivity in subjects with increased risk of developing NIDDM [5-16, 46-52] groups were well matched in terms of age, gender and BMI. Although there is abundant evidence in the literature [for review, 18 and 53] that maximal aerobic power is significantly correlated to insulin-stimulated glucose disposal (in the current study we found an $r^{2}$ at 0.46 in the relatives and 0.44 in the control subjects), maximal oxygen uptake has only been measured in one of the former reports [6]. Laws et al. [6], however, found relatives of NIDDM subjects to be insulin resistant as assessed by the insulin suppression test despite having comparable $\mathrm{VO}_{2}$ max values to those found in control 


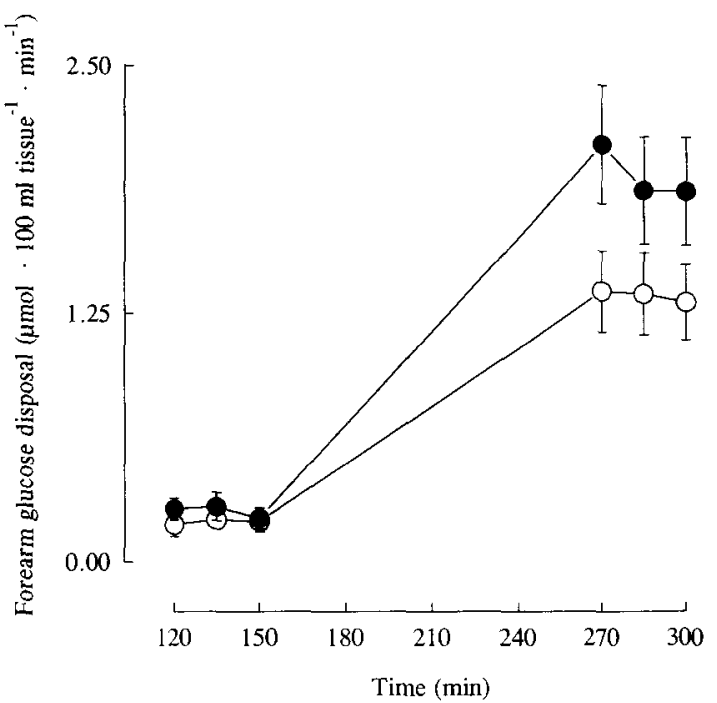

Fig.5. Forearm glucose disposal (mean \pm SEM) in relatives of patients with NIDDM $(O)$ and control subjects $(O)$ during the basal period (time, $120-150 \mathrm{~min}$ ) and the hyperinsulinaemic clamp (time, $270-300 \mathrm{~min}$ ). $p<0.05$ (ANOVA)

subjects, suggesting that factors other than impaired physical fitness appear to contribute to the insulin resistance of the relatives. The discrepancy between their study and ours might be due to notable differences in body composition and physical activity. $\mathrm{VO}_{2}$ max was considerably lower and all were overweight (120-160\% of ideal body weight) implying that the impact of physical activity on insulin action could be partly concealed by an obesity-related insulin resistance.

Whilst the questionnaire quantifying physical activity both during work and leisure times showed similar levels in the two groups, the maximal aerobic power was significantly higher in the control subjects. Though a questionnaire may be fraught by uncertainty, this finding together with the reduced maximal aerobic capacity of the relatives might be grounded in differences/abnormalities in skeletal muscle fibre composition, capillary density and also perhaps in abnormalities in the skeletal muscle phospholipids [54]. An association between fibre composition and density of capillaries vs insulin sensitivity has been recognized for more than a decade [55], and has been confirmed by Lillioja et al. [56] who using the clamp technique demonstrated correlations between insulin-stimulated glucose disposal rates and capillary density, percentage of type I fibres and percentage of type II B fibres (an inverse relationship), and analogous correlations were seen between $\mathrm{VO}_{2} \max$ and the muscle morphology. Recently, it has been shown that subjects with abdominal obesity (with and without NIDDM) exhibit a low percentage of type I fibres and a low capillary density [57], but whether such variations are ascribable to genetic factors or environmental factors (including secondary hyperinsulinaemia, [58]) is not known. The $\mathrm{W} / \mathrm{H}$ ratios were similar in our two groups, but it should be noted that the ability of this classic measurement to estimate the amount of the visceral fat deposits is limited [59]. The content of intraabdominal fat has been suggested to be an important determinator of the insulin sensitivity in men with NIDDM [60].

The coupling of insulin resistance and lack of physical fitness in relatives of NIDDM subjects is parallel to findings in another facet of the metabolic syndrome, namely essential hypertension [61, 62]. Offspring of hypertensive subjects exhibit impaired insulin-stimulated glucose metabolism [63], which is apparently related to maximal oxygen uptake [64].

Examining forearm A-V balances our study demonstrates for the first time direct evidence of reduced insulin-stimulated extraction of glucose in skeletal muscle in relatives of NIDDM patients. This finding is, however, not unexpected bearing in mind the work of DeFronzo et al. [65] indicating that 80-90\% of plasma glucose removal during hyperinsulinaemia is confined to skeletal muscle in healthy humans and studies in relatives of NIDDM patients showing abnormalities in pivotal intracellular processings of muscle cells, e.g. the activities of glycogen synthase [11] and tyrosine kinase [66]. Based upon indirect calorimetry our study is in line with Eriksson et al. [5], Vaag et al. [11] and Gulli et al. [12] all finding that mainly/only non-oxidative insulin-stimulated glucose disposal is affected in relatives. The diminished nonoxidative glucose disposal has been assumed to be due to impaired storage of glycogen which is the major non-oxidative event during short-term moderate insulin exposure, but lactate and alanine formation and release are other important non-oxidative events. However, the arterialized concentrations and the A$\mathrm{V}$ differences of the two metabolites were not different between the relatives and the control subjects. In addition, we support previous data indicating that the restraining effect of insulin on HGP is normal in relatives of NIDDM patients. Employing the hot glucose infusion protocol approach our design, however, allows assessment of the time-course of effects of insulin on the liver.

As mentioned before a reduced insulin-stimulated blood flow has been suggested to be one cardinal factor behind insulin resistance in obesity and NIDDM [23-26]. In the present study neither basal forearm blood flow, insulin-stimulated blood flow nor the incremental blood flow significantly influenced insulin-stimulated glucose disposal, thus not supporting differences in the blood flow as being major determinants for the insulin resistance of our relatives of NIDDM patients. The findings on forearm blood flow warrant two comments. First, the muscle mass of the forearm constitutes less than $10 \%$ of the total body muscle mass and there may be some heterogeneity in the ability of insulin to increase blood flow 
in other regions. Second, our observation of an increment in forearm blood flow during the hyperinsulinaemic euglycaemic clamp (both in relatives and in control subjects) seems difficult to reconcile with previous reports where even pharmacologic doses of insulin failed to modulate forearm blood flow significantly [67].

All subjects had a normal glucose tolerance; however, the average plasma glucose concentrations were higher 60,90 and $120 \mathrm{~min}$ after the glucose ingestion in the relatives suggesting a relative glucose intolerance. Circulating insulin concentrations before and after the oral glucose were assayed not only by employing a traditional RIA but also an ELISA using a two-site immunoassay, which do not detect proinsulin, split (32-33)- and des(31, 32)-proinsulin, the latter being the only proinsulin products present in significant amounts in circulation. Basal levels of circulating insulin were comparable in the two groups, irrespective of the assay, whilst the patterns of the post-glucose insulin curves differed substantially in the two assays. Using the traditional (non-specific) assay serum insulin peaked after $30 \mathrm{~min}$ in both groups, and was consistently elevated in the relatives as compared to the control subjects, while the rise in serum insulin in the relatives using the two-site assay was clearly delayed (and exhibited a pattern comparable to that of circulating C-peptide). This strongly indicates that the initial insulin release of the relatives includes a large fraction of proinsulin and splitproducts, thus substantiating the composite pathogenesis of NIDDM. A nonsignificant difference in fasting insulin in the two groups is not contradictory to the presence of insulin resistance in the relatives, because the majority of basal glucose disposal takes place in non-insulin-dependent tissues [68]. Moreover, the insulin resistance may be compensated for by a slight elevation of blood glucose $\left(\mathrm{HbA}_{1 \mathrm{c}}\right.$ tended to be higher in the relatives, $p=0.09$ ), and could also be through an exaggerated glucose effectiveness [13]. Our findings support the notion of an early betacell dysfunction in prediabetic subjects and are thus in line with the data of Pimenta et al. [52] demonstrating a diminished first- and second-phase insulin response in relatives during a hyperglycaemic clamp.

An increasing amount of evidence from both epidemiological and from case-control studies indicate a clustering of insulin resistance, hypertension, dyslipidaemia, NIDDM and obesity, with insulin resistance playing a pivotal role $[63,69,70]$. In addition, microalbuminuria has lately been suggested to be associated with insulin resistance in NIDDM [71] and to be a predictor of NIDDM [72]. The present study did not show any significant differences in the $24-\mathrm{h}$ ambulatory blood pressure and the lipid variables between the relatives and the control subjects. Furthermore, urinary albumin/creatinine ratios were comparable in the two groups. Obviously, this may partly be due to the limited number of participants, but probably also relates to the heterogeneity of this syndrome.

In conclusion, relatives of patients with NIDDM are characterized by impaired insulin-stimulated glucose uptake in skeletal muscle when compared to an age and anthropometrically matched control group without any family history of diabetes mellitus. This abnormality seems, however, to be associated with a diminished maximal aerobic uptake. Whether the reduced physical fitness of the relatives is due to environmental or genetic factors remains to be elucidated.

Acknowledgements. We thank Ms. L. Truds $\emptyset$, Ms. L. Korsgaard, Ms. I. Bisgaard and Ms. L. Ashwatt for excellent technical assistance. The study was supported by the Institute of Clinical Experimental Research, University of Aarhus and Novo Nordisk Farmaka, Copenhagen, Denmark and the British Diabetic Association.

\section{References}

1. DeFronzo RA (1988) The triumvirate: $\beta$-cell, muscle, liver. A collusion responsible for NIDDM. Diabetes 37: 667-687

2. Yki-Järvinen H (1994) Pathogenesis of non-insulin-dependent diabetes mellitus. Lancet 343: 91-95

3. Beck-Nielsen H, Groop L (1994) Metabolic and genetic characterization of prediabetic states. J Clin Invest 94: 1714-1721

4. Lillioja S, Mott DM, Zawadzki JK et al. (1987) In vivo insulin action is familial characteristic in nondiabetic Pima Indians. Diabetes 36: 1329-1335

5. Eriksson J, Franssila-Kallunki A, Ekstrand A et al. (1989) Early metabolic defects in persons at increased risk for non-insulin-dependent diabetes mellitus. N Engl J Med 321: 337-343

6. Laws A, Stefanick ML, Reaven GM (1989) Insulin resistance and hyper- triglyceridemia in nondiabetic relatives of patients with noninsulin-dependent diabetes mellitus. J Clin Endocrinol Metab 69: 343-347

7. Ho LT, Chang ZY, Wang JTet al. (1990) Insulin insensitivity in offspring of parents with type 2 diabetes mellitus. Diabet Med 7: 31-34

8. O'Rahilly SP, Rudenski AS, Burnett MA et al. (1986) Betacell dysfunction, rather than insulin insensitivity, is the primary defect in familial type 2 diabetes. Lancet ii:360-363

9. Osei K, Cottrell DA, Orabella MM (1991) Insulin sensitivity, glucose effectiveness, and body fat distribution pattern in nondiabetic offspring of patients with NIDDM. Diabetes Care 14: 890-896

10. Martin BC, Warram JH, Rosner B, Rich SS, Soeldner JS, Krolewski AS (1992) Familial clustering of insulin sensitivity. Diabetes 41: 850-854

11. Vaag A, Henriksen JE, Beck-Nielsen H (1992) Decreased insulin activation of glycogen synthase in skeletal muscles in young nonobese Caucasian first degree relatives of patients with non-insulin-dependent diabetes mellitus. J Clin Invest 89: 782-788

12. Gulli G, Ferrannini E, Stern M, Haffner S, DeFronzo RA (1992) The metabolism profile of NIDDM is fully established in glucose-tolerant offspring of two Mexican-American NIDDM parents. Diabetes 41: 1575-1586 
13. Henriksen JE, Alford F, Handberg A et al. (1994) Increased glucose effectiveness in normoglycemic but insulin-resistant relatives of patients with non-insulin-dependent diabetes mellitus. A novel compensatory mechanism. J Clin Invest 94: 1196-1204

14. Warram JH, Martin BC, Krolewski AS, Soeldner JS, Kahn CR (1990) Slow glucose removal rate and hyperinsulinemia precede the development of type II diabetes in the offspring of diabetic parents. Ann Intern Med 113: 909-915

15. Martin BC, Warram JH, Krolewski AS, Bergman RN, Soeldner JS, Kahn CR (1992) Role of glucose and insulin resistance in development of type 2 diabetes mellitus: results of a 25-year follow-up study. Lancet 340: 925-929

16. Lillioja S, Mott DM, Spraul M et al. (1993) Insulin resistance and insulin secretory dysfunction as precursors of non-insulin-dependent diabetes mellitus. N Engl J Med 329: 1988-1992

17. Rosenthal M, Haskell WL, Solomon R, Widstrom A, Reaven GM (1983) Demonstration of a relationship between level of physical training and insulin-stimulated glucose utilization in normal humans. Diabetes 32: 408-411

18. Koivisto VA, Yki-Järvinen H, DeFronzo RA (1986) Physical training and insulin sensitivity. Diabetes Metab Rev 1: 445-481

19. Devlin JT, Horton ES (1985) Effects of prior high-intensity exercise on glucose metabolism in normal and insulin-resistant men. Diabetes 34: 973-979

20. Mikines KJ, Sonne B, Farrell PA, Tronier B, Galbo H (1988) Effect of physical exercise on sensitivity and responsiveness to insulin in humans. Am J Physiol 254:E248-E259

21. Helmrich SP, Ragland DR, Leung RW, Paffenbarger RS (1991) Physical activity and reduced occurrence of non-insulin-dependent diabetes mellitus. N Engl J Med 325: 147152

22. Manson JE, Rimm EB, Stampfer MJ et al. (1991) Physical activity and incidence of non-insulin-dependent diabetes mellitus in women. Lancet 338: 774-778

23. Laakso M, Edelman SV, Brechtel G, Baron AD (1990) Decreased effect of insulin to stimulate skeletal muscle blood flow in obese man. A novel mechanism for insulin resistance. J Clin Invest 85: 1844-1852

24. Baron AD, Laakso M, Brechtel G, Edelman SV (1991) Reduced capacity and affinity of skeletal muscle for insulinmediated glucose uptake in non-insulin-dependent diabetic subjects. Effects of insulin therapy. J Clin Invest 87: 11861194

25. Laakso M, Edelman SV, Brechtel G, Baron AD (1992) Impaired insulin-mediated skeletal muscle blood flow in patients with NIDDM. Diabetes 41: 1076-1083

26. Baron AD, Brechtel G (1993) Insulin differentially regulates systemic and skeletal muscle vascular resistance. Am J Physiol 265:E61-E67

27. Feldman RD, Bierbrier GS (1993) Insulin-mediated vasodilation: impairment with increased blood pressure and body mass. Lancet 342: 707-709

28. Gray SD (1989) Effect of obesity on bioelectrical impedance. Am J Clin Nutr 50: 255-260

29. Åstrand I (1960) Aerobic work capacity of men and women with special reference to age. Acta Physiol Scand [Suppl] 169: 49-92

30. Lindegärde F, Saltin B (1981) Daily physical activity, work capacity and glucose tolerance in lean and obese normoglycaemic middle-aged men. Diabetologia 20: 134-138

31. Berntorp K, Eriksson KF, Lindegärde F (1986) The importance of diabetes heredity in lean subjects on insulin action, blood lipids and oxygen uptake in the pathogenesis of glucose intolerance. Diabetes Res 3: 231-236
32. Saltin B, Grimby G (1968) Physiological analysis of middle-aged and old former athletes. Circulation 38: 1104-1115

33. Hansen KW, Mau Pedersen M, Marshall SM, Christiansen JS, Mogensen CE (1992) Circadian variation of blood pressure in patients with diabetic nephropathy. Diabetologia 35: 1074-1079

34. Pedersen B, Møller N, Nielsen OH, Schmitz O (1989) Contamination of tritiated glucose tracers. Diabete Metab 15: $102-103$

35. DeFronzo RA, Tobin JD, Andres R (1979) Glucose clamp technique: a method for quantifying insulin secretion and resistance. Am J Physiol 237:E214-E223

36. Finegood DT, Bergman RN, Vranic M (1987) Estimation of endogenous glucose production during hyperinsulinemic-euglycemic glucose clamps: comparison of unlabelled and labelled exogenous glucose infusates. Diabetes 36 : 914-924

37. Frayn KN (1983) Calculation of substrate oxidation rates in vivo from gaseous exchange. J Appl Physiol 55: 628-634

38. Whitney RJ (1953) The measurement of volume changes in human limbs. J Physiol 121: 1-27

39. Møller N, Jørgensen JOL, Schmitz O et al. (1990) Effects of a growth hormone pulse on total and forearm substrate fluxes in humans. Am J Physiol 258:E86-E91

40. Ørskov H, Thomsen HG, Yde H (1968) Wick-chromatography for rapid and reliable immunoassay of insulin, glucagon and growth hormone. Nature 219: 193-197

41. Andersen L, Dinesen B, Jørgensen PN, Poulsen F, Røder ME (1993) Enzyme immunoassay for intact human insulin in serum or plasma. Clin Chem. 39: 578-582

42. Heding L (1975) Radioimmunological determination of human C-peptide in serum. Diabetologia 11: 541-548

43. Harrison J, Hodson AW, Skillen AW, Stappenbeck R, Agius L, Alberti KGMM (1988) Blood glucose, lactate, pyruvate glycerol, 3-hydroxybutyrate and acetoacetate measurements in man using a centrifugal analyser with a fluorimetric attachment. J Clin Chem Clin Biochem 26: 141-146

44. National Diabetes Data Group (1979) Classification and diagnosis of diabetes mellitus and other categories of glucose intolerance. Diabetes 28: 1039-1057

45. Cooper KE, Edholm OG, Mottram RF (1955) The blood flow in skin and muscle of the human forearm. J Physiol 128: 258-267

46. Aronoff SL, Bennet PH, Gorden P, Rushforth N, Miller M (1977) Unexplained hyperinsulinemia in normal and 'prediabetic' Pima Indians compared with normal Caucasians. Diabetes 26: 827-840

47. Leslie RDG, Volkmann HP, Poncher M, Hanning I, Orskov H, Alberti KGMM (1986) Metabolic abnormalities in children of non-insulin dependent diabetics. BMJ 293: $840-842$

48. Haffner SM, Stern MP, Hazuda HP, Pugh JA, Patterson JK (1986) Hyperinsulinemia in a population at high risk for non-insulin-dependent diabetes mellitus. N Engl J Med 315: $220-224$

49. Haffner SM, Stern MP, Hazuda HP, Mitchell BD, Patterson JK (1988) Increased insulin concentration in nondiabetic offspring of diabetic parents. N Engl J Med 319: 1297-1301

50. Saad MF, Pettitt DJ, Mott DM, Knowler WC, Nelson RG, Bennett PH (1989) Sequential changes in serum insulin concentration during development of non-insulin-dependent diabetes. Lancet $\mathrm{I}: 1356-1359$

51. Lillioja S, Nyomba BL, Saad MF et al. (1991) Exaggerated early insulin release and insulin resistance in a diabetesprone population: a metabolic comparison of Pima Indians and Causasians. J Clin Endocrinol Metab 73: 866-876 
52. Pimenta W, Korytkowski M, Mitrakou A et al. (1995) Pancreatic beta-cell dysfunction as the primary genetic lesion in NIDDM. JAMA 273: 1855-1861

53. Horton ES (1986) Exercise and physical training: effects on insulin sensitivity and glucose metabolism. Diabetes Metab Rev 2: $1-17$

54. Borkman M, Storlien LH, Pan DA, Jenkins AB, Chisholm DJ, Campbell LV (1993) The relationship between insulin sensitivity and the fatty-acid composition of skeletal-muscle phospholipids. N Engl J Med 328: 238-244

55. Lithell H, Lindegärde F, Hellsing K, Lundquist G, Nygaard E, Saltin B (1981) Body weight, skeletal muscle morphology, and enzyme activities in relation to fasting serum insulin concentration and glucose tolerance in 48-year-old men. Diabetes 30: 19-25

56. Lillioja S, Young AA, Culter CL et al. (1987) Skeletal muscle capillary density and fiber type are possible determinants of in vivo insulin resistance in man. J Clin Invest 80: 415-424

57. Mårin P, Anderson B, Krotkiewski M, Björntorp P (1994) Muscle fibre composition and capillary density in women and men with NIDDM. Diabetes Care 17: 382-386

58. Holmäng A, Brzezinska Z, Björntorp P (1993) Effects of hyperinsulinemia on muscle fiber composition and capillarization in rats. Diabetes 42: 1073-1081

59. Després JP, Prud-homme D, Pouliot MC, Tremblay A, Bouchard C (1991) Estimation of deep abdominal adipose tissue accumulation from simple anthropometric measurements in men. Am J Clin Nut 54: 471-477

60. Banerji MA, Chaiken RL, Gordon D, Kral JG, Lebovitz HE (1995) Does intra-abdominal adipose tissue in black men determine whether NIDDM is insulin-resistant or insulin-sensitive? Diabetes 44: 141-146

61. Ferrannini E, Buzzigoli G, Bonadona R et al. (1987) Insulin resistance in essential hypertension. $\mathrm{N}$ Engl J Med 317: 350-357

62. Reaven GM (1988) Role of insulin resistance in human disease. Diabetes 37: 1595-1607
63. Beatty OL, Harper R, Sheridan B, Atkinson AB, Bell PM (1993) Insulin resistance in offspring of hypertensive parents. BMJ 307: 92-96

64. Endre T, Mattiasson I, Hulten UL, Lindegärde F, Berglund $G$ (1994) Insulin resistance is coupled to low physical fitness in normotensive men with a family history of hypertension. J Hypertension 12: 81-88

65. DeFronzo RA, Jacot E, Jequier E, Maeder E, Wahren J, Felber JP (1981) The effect of insulin on the disposal of intravenous glucose. Diabetes 30: 1000-1007

66. Handberg A, Vaag A, Vinten J, Beck-Nielsen H (1993) Decreased tyrosine kinase activity in partially purified insulin receptors from muscle of young, non-obese first degree relatives of patients with type 2 (non-insulin-dependent) diabetes mellitus. Diabetologia 36: 668-674

67. Yki-Järvinen H, Young AA, Lamkin C, Foley JE (1987) Kinetics of glucose disposal in whole body and across the forearm in man. J Clin Invest 79: 1713-1719

68. Felber JP, Thièbaud D, Maeder E, Jèquier E, Hendler R, DeFronzo RA (1983) Effect of somatostatin-induced insulinopenia on glucose oxidation in man. Diabetologia 25: 325-330

69. DeFronzo RA, Ferrannini E (1991) Insulin resistance. A multifaceted syndrome responsible for NIDDM, obesity, hypertension, dyslipidemia, and atherosclerotic cardiovascular disease. Diabetes Care 14: 173-194

70. Reaven GM, Laws A (1994) Insulin resistance, compensatory hyperinsulinemia, and coronary heart disease. Diabetologia 37: 948-952

71. Groop L, Ekstrand A, Forsblom C et al. (1993) Insulin resistance, hypertension and microalbuminuria in patients with type 2 (non-insulin-dependent) diabetes mellitus. Diabetologia 36: 642-647

72. Mykkanen L, Haffner SM, Kuusisto J, Pyrörälä K, Laakso M (1994) Microalbuminuria precedes the development of NIDDM. Diabetes 43: 552-557 